\title{
Hubungan pengetahuan gizi ibu dengan kecukupan asupan energi anak usia 1-3 tahun di Desa Mopusi Kecamatan Lolayan Kabupaten Bolaang Mongondow Sulawesi Utara
}

\author{
${ }^{1}$ Tasya Watania \\ ${ }^{2}$ Nelly Mayulu \\ ${ }^{2}$ Shirley E. S. Kawengian \\ ${ }^{1}$ Kandidat Skripsi Fakultas Kedokteran Universitas Sam Ratulangi Manado
${ }^{2}$ Bagian Ilmu Gizi Fakultas Kedokteran Universitas Sam Ratulangi Manado
Email: wataniatasya@ gmail.com
}

\begin{abstract}
Nutritional adequacy or sufficiency of energy in infants is still a public health problem, especially in developing countries and poor countries. As a developing country, Indonesia still has macronutrient deficiencies such as stunting, wasting, and underweight. Maternal level of knowledge about nutrition influences the attitude and behavior in chosing the appropriate and qualified food. This study was aimed to determine the relationship between maternal knowledge and the adequacy of energy intake of toddlers at Mopusi village. This was a correlation study with a cross sectional design. Respondents of this study were mothers who had toddlers aged 1-3 years and lived at Mopusi vollage in September 2014 - December 2014. Data were analyzed by using SPSS. The results showed that there were 90 mothers as respondents. Based on maternal knowledge about nutrition, there were 41 respondents (45.6\%) with poor knowledge. Based on adequate intake of energy toddlers, there were 75 toddlers $(83 \%)$ with less energy intake. The relationship between maternal knowledge about nutrition and the adequacy of energy intake among toddlers showed the correlation coefficient $r=0.06$ and $p=0.97$. Conclusion: There was no significant correlation between maternal knowledge about nutrition and the adequacy of energy intake among toddlers at Mopusi village.
\end{abstract}

Keywords: mother's knowledge about nutritions, energy intake, toddlers

\begin{abstract}
Abstrak: Kecukupan gizi atau kecukupan energi pada balita masih menjadi masalah kesehatan masyarakat terutama dinegara-negara berkembang dan negara miskin. Sebagai negara berkembang, Indonesia mempunyai masalah defisiensi makronutrien antara lain stunting, wasting dan underweight. Tingkat pengetahuan gizi seseorang ibu berpengaruh terhadap sikap dan perilaku dalam pemilihan makanan. Penelitian ini bertujuan untuk mengetahui hubungan antara pengetahuan ibu dengan kecukupan asupan energi batita di Desa Mopusi Kecamatan Lolayan Kabupaten Bolaang Mongondow Induk. Jenis penelitian ialah korelasi dengan desain potong lintang. Responden penelitian ialah ibu yang memiliki batita usia 1-3 tahun dan berdomisili di Desa Mopusi pada bulan September 2014 Desember 2014. Data dianalisis menggunakan SPSS. Hasil penelitian mendapatkan sebanyak 41 responden $(45,6 \%)$ berpengetahuan gizi kurang. Mengenai kecukupan asupan energi dari 90 sampel penelitian terdapat 75 batita (83\%) dengan asupan energi kurang. Hubungan pengetahuan gizi ibu dengan kecukupan asupan energi batita mendapatkan koefisien korelasi $r=0,06$ dan $p=0,97$. Simpulan: Tidak terdapat hubungan bermakna antara pengetahuan gizi ibu dengan kecukupan asupan energi batita di Desa Mopusi.
\end{abstract}

Kata kunci: pengetahuan gizi ibu, asupan energi, batita. 
Masalah gizi merupakan salah satu masalah kesehatan di dunia. Program millenium development goals yang dicanangkan PBB salah satunya adalah program pengurangan mortalitas anak pada poin keempat. ${ }^{1}$ Mortalitas anak terkait dengan masalah gizi, seperti yang dipublikasi oleh WHO bahwa satu pertiga dari kematian anak berhubungan langsung dengan malnutrisi. ${ }^{2}$ Penelitian Pelletier et al. ${ }^{3}$ menunjukkan bahwa di 53 negara berkembang, 56\% kematian pada anak terkait dengan efek malnutrisi yang berpotensi terhadap penyakit infeksi.

Kecukupan gizi atau kecukupan energi pada balita masih menjadi masalah kesehatan masyarakat terutama dinegaranegara berkembang dan negara miskin. Prevalensi stunting, wasting dan underweight masih tinggi dinegara-negara dengan income per kapita rendah. Prevalensi gizi kurang pada anak usia pra sekolah di Afrika mencapai 14-36.5\%, di Asia 28,9 - 43.6\% dan di Amerika latin $3.2-15.4 \%$. ${ }^{4}$ Sebagai negara berkembang Indonesia mempunyai masalah defisiensi makronutrien. Stunting, wasting dan underweight merupakan masalah defisiensi makronutrien yang ada di Indonesia. ${ }^{5}$ Kelompok usia balita merupakan populasi berisiko terhadap kasus defisiensi makronutrien dan mikronutrien di Indonesia. $^{6}$

Kurang lebih 1/3 kematian anak balita penyebabnya didasari oleh kekurangan gizi, termasuk diantaranya stunting dan wasting yang sangat berat, defisiensi vitamin A, defisiensi zink dan pemberian ASI yang kurang optimal. Malnutrisi pada anak paling sering terjadi di Negara-negara berpenghasilan rendah dan menyerang anak usia 6 sampai 18 bulan. $^{7}$

Angka kecukupan Gizi 2013 bagi orang Indonesia mencantumkan bahwa kebutuhan zat gizi makronutrien pada balita harus mencapai $1125 \mathrm{Kkal}^{8}{ }^{8}$ Status gizi yang baik dihasilkan dari pola makan yang seimbang, yaitu sesuai dengan kebutuhan disertai dengan pemilihan bahan makanan yang tepat. Asupan makanan yang kurang dari yang dibutuhkan akan menyebabkan tubuh menjadi kurus dan rentan penyakit.

Indonesia telah berada dalam jalur yang benar untuk mencapai Millenium Development Goals (MDGs) no. 1, yaitu dalam mengurangi kemiskinan. Salah satu yang masih harus diperhatikan adalah jumlah penduduk rawan pangan (dimana konsumsi energi kurang dari 1400 $\mathrm{Kkal} /$ hari/kapita atau kurang dari $70 \%$ dari Angka Kecukupan Gizi di Indonesia pada tahun 2009 sebesar 14,47\%, sedangkan untuk target MDGs tahun 2015 yaitu 8,5\%, sehingga masih diperlukan kerja yang lebih keras untuk menurunkan jumlah penduduk rawan pangan tersebut. ${ }^{9}$

Energi sangat penting bagi kehidupan. Seluruh gerak tubuh manusia, seperti berdiri, berjalan, bahkan tidur memerlukan energi. ${ }^{10}$ Bila terjadi defisiensi maka akan terjadi malnutrisi, stunting dan terjadi defisit yang permanen. ${ }^{11}$

Pengetahuan gizi merupakan pengetahuan tentang makanan dan zat gizi, sumber-sumber zat gizi pada makanan, makanan yang aman dikonsumsi sehingga tidak menimbulkan penyakit, dan cara mengolah makanan yang baik agar zat gizi dalam makanan tidak hilang. Tingkat pengetahuan gizi seseorang ibu berpengaruh terhadap sikap dan perilaku dalam pemilihan makanan. Pengetahuan gizi yang tidak memadai, kurangnya pengetahuan tentang kebiasaan makan yang baik, serta pengertian yang kurang tentang kontribusi gizi dari berbagai jenis makanan akan menimbulkan masalah kecerdasan dan produktivitas terutama pada batita atau dikenal juga dengan anak yang berusia antara 1-3 tahun.

Hasil pengamatan penulis di Desa Mopusi menunjukkan bahwa yang berperan dalam merawat bayi lebih banyak dilakukan oleh ibu kandung bayi dengan berbagai variasi tingkat pendidikan, mulai dari sekolah dasar sampai perguruan tinggi. Tujuan penelitian ini untuk mengetahui hubungan tingkat pengetahuan gizi ibu dengan asupan energi anak batita di Desa Mopusi Kecamatan Lolayan Kabupaten Bolaang Mongondow Induk. 


\section{METODE DAN BAHAN PENELITIAN}

Jenis penelitan ini ialah analitik dengan desain potong lintang. Penelitian dilaksanakan di Desa Mopusi Kota Kotamobagu pada bulan September sampai Desember tahun 2014. Populasi penelitian ialah seluruh anak usia 1-3 tahun yang berdomisili di Desa Mopusi Kecamatan Lolayan Kabupaten Bolaang Mongondow Induk yaitu sebanyak 165 batita. Sampel penelitian berjumlah 90 batita diambil melalui metode purposive sampling.

Pengetahuan kecukupan asupan energi adalah segala sesuatu yang diketahui oleh responden tentang hal yang berkaitan dengan kecukupan asupan energi anak balita. Untuk mengukur pengetahuan responden digunakan kuesioner tentang pengetahuan ibu tentang gizi anak yang telah diuji validitas. Kuesioner ini berisi 21 pertanyaan dengan menggunakan sistem skoring dimana total jawaban yang benar dikalikan 100 dan dibagi dengan jumlah pertanyaan. Berdasarkan total skor yang diperoleh kemudian diklasifikasikan ke dalam 3 kategori menurut Khomsan: Baik: Skor >80; Cukup: Skor 60-80; Kurang: Skor <60 (Skala ordinal). ${ }^{12}$

Asupan energi adalah asupan zat karbohidrat, lemak, protein yang diperoleh dari sejumlah makanan yang dikonsumsi oleh seorang individu per hari yang di data menggunakan metode food recall 24 hours, dilakukan dua hari berturut-turut. Metode ini ialah metode wawancara, dimana pewawancara menanyakan apa yang dikonsumsi oleh responden. ${ }^{11}$ Data ini kemudian diolah menggunakan program Nutrisurvey untuk mengetahui nilai rekomendasi asupan dan jumlah asupan zat karbohidrat, protein dan lemak yang dikonsumsi anak batita dari responden per hari. Dengan metode ini akan diketahui besarnya porsi pangan berdasarkan ukuran rumah tangga (urt), kemudian dikonversi ke ukuran metric $(g){ }^{13,14}$ Dari program Nutrisurvey didapatkan asupan energi hari pertama dan hari kedua. Asupan energi rata-rata dalam dua hari tersebut didapatkan dari jumlah recall hari pertama dan hari ke dua kemudian dibagi dua. Untuk mendapatkan tingkat kecukupan asupan energi berdasarkan AKG diperlukan rumus sebagai berikut:

$$
\begin{aligned}
& \text { AKG Energi Individu } \\
& =\frac{\text { berat responden }}{\text { berat standart }} \times A K G \text { standart batita } \\
& \% A K G \text { energ } i=\frac{\text { asupan energi }}{A K G \text { energi individu }} \times 100 \%
\end{aligned}
$$

Klasifikasi kebutuhan energi dibagi menjadi tiga dengan ambang batas masingmasing sebagai berikut:

Tabel 1. Tingkat kecukupan energi berdasarkan $\mathrm{AKG}^{12}$

\begin{tabular}{cc}
\hline $\begin{array}{c}\text { Kategori } \\
\text { kecukupan energi }\end{array}$ & \% AKG \\
\hline Kurang & $<90 \%$ \\
Cukup & $90-110 \%$ \\
Lebih & $>110 \%$ \\
\hline
\end{tabular}

Analisis data mengenai gambaran tingkat pengetahuan ibu dan kecukupan asupan energi anak batita yang telah diolah dianalisis secara univariat dan selanjutnya secara bivariat untuk mengetahui hubungan pengetahuan ibu dengan kecukupan asupan energi pada batita dengan menggunakan uji Spearman Rank pada tingkat kemaknaan 95\% $(\alpha=0,05)$ dengan bantuan program SPSS versi 20.00 .

\section{HASIL PENELITIAN}

Penelitian ini dilaksanakan di Desa Mopusi Kecamatan Lolayan Kabupaten Bolaang Mongondow Induk, Sulawesi Utara. Desa Mopusi ini memiliki 165 ibu yang mempunyai anak umur 1-3 tahun, dan yang menjadi sampel yaitu 90 orang. Karakteristik sampel dapat dilihat pada Tabel 2.

Pengetahuan gizi ibu anak usia 1-3 tahun dinilai berdasarkan pertanyaan-pertanyaan pada kuesioner yang dijawab oleh para responden. Berdasarkan hasil penelitian, diketahui bahwa jumlah responden yang berpengetahuan kurang lebih banyak daripada yang berpengetahuan baik. Berdasarkan hasilnya sebanyak 11 responden $(12,2 \%)$ berpengetahuan baik mengenai gizi; 38 responden $(42,2 \%)$ berpengetahuan 
Watania, Mayulu, Kawengian: Hubungan pengetahuan gizi...

cukup; dan 41 responden
berpengetahuan kurang (Tabel 3).

Tabel 2. Distribusi karakteristik sampel

\begin{tabular}{llcc}
\hline \multicolumn{2}{c}{ Karakteristik responden } & n & \% \\
\hline Jenis kelamin & Perempuan & 52 & 57,8 \\
Usia ibu & Laki- laki & 38 & 42,2 \\
& $15-25$ tahun & 64 & 71 \\
Pekerjaan ibu & $26-34$ tahun & 25 & 27,8 \\
& $>35$ tahun & 1 & 1,1 \\
& IRT & 78 & 86,7 \\
& Petani & 4 & 4,4 \\
& Pedagang & 3 & 3,3 \\
& Mahasiswi & 2 & 2,2 \\
& Perawat Gigi & 1 & 1,1 \\
Pendidikan & Sekolah & 1 & 1,1 \\
ibu & Tambang & 1 & 1,1 \\
& SD & 37 & 41,1 \\
& SMP & 34 & 37,8 \\
& SMA & 16 & 17,8 \\
& PT & 3 & 3,3 \\
\hline
\end{tabular}

Tabel 3. Distribusi pengetahuan gizi ibu

\begin{tabular}{ccc}
\hline Pengetahuan gizi ibu & n & \% \\
\hline Baik & 11 & 12,2 \\
Sedang & 38 & 42,2 \\
Kurang & 41 & 45,6 \\
\hline
\end{tabular}

Berdasarkan jenis kelamin, sampel laki laki sebanyak 38 batita $(42,2 \%)$ dan perempuan sebanyak 52 batita $(57,8 \%)$. Berdasarkan usia, yang berusia 12-19 bulan sebanyak 42 batita $(46,7 \%)$ serta merupakan distribusi terbanyak; yang berusia 20-28 bulan sebanyak 36 batita (40,0\%), dan yang berusia 29-36 bulan sebanyak 12 batita $(13,3 \%)$ serta merupakan distribusi paling rendah (Tabel 4).
Tabel 4. Karakteristik batita

\begin{tabular}{cccc}
\hline \multicolumn{2}{c}{ Karakteristik Batita } & n & \% \\
\hline Jenis kelamin & Laki- laki & 38 & 42.2 \\
& Perempuan & 52 & 57.8 \\
Usia Batita & $12-19$ bulan & 42 & 46.7 \\
& $20-28$ bulan & 36 & 40 \\
& $29-36$ bulan & 12 & 13.3 \\
\hline
\end{tabular}

Asupan energi diperoleh melalui recall 24 jam. Dari 90 sampel penelitian, terdapat 75 batita (83\%) dengan asupan energi kurang dan merupakan distribusi tertinggi; 8 batita $(8,9 \%)$ dengan asupan energi cukup; dan 7 batita $(7,8 \%)$ dengan asupan energi tinggi yang merupakan distribusi paling rendah.

Berdasarkan analisis statistik dengan menggunakan uji korelasi Spearman rank pada tingkat pengetahuan gizi ibu dengan kecukupan asupan energi batita diperoleh hasil koefisien korelasi $r=0,06$ dan $p=0,97$ hasil ini menunjukkan bahwa tidak ada hubungan bermakna antara keduanya. Data mengenai hubungan antara tingkat pengetahuan gizi ibu dengan kecukupan asupan energi batita dapat dilihat pada tabel berikut.

Tabel 5. Distribusi responden berdasarkan kecukupan asupan energi batita

\begin{tabular}{ccc}
\hline $\begin{array}{c}\text { Kecukupan } \\
\text { asupan energi batita }\end{array}$ & $\mathbf{n}$ & $\boldsymbol{\%}$ \\
\hline Kurang & 75 & 83 \\
Cukup & 8 & 8,9 \\
Lebih & 7 & 7,8 \\
\hline
\end{tabular}

Tabel 6. Hubungan antara tingkat pengetahuan ibu dengan kecukupan asupan energi batita.

\begin{tabular}{ccccccc}
\hline \multirow{2}{*}{ Pengetahuan gizi } & \multicolumn{3}{c}{ Asupan energi } & \multirow{2}{*}{ Total } & \multirow{2}{*}{ r } & \multirow{2}{*}{$\mathbf{p}$} \\
\cline { 2 - 4 } & kurang & cukup & lebih & & \\
\hline Baik & $9(10 \%)$ & $2(2,20 \%)$ & $0(0 \%)$ & $10(12,20 \%)$ & & \\
Sedang & $32(35,60 \%)$ & $2(2,20 \%)$ & $4(4,40)$ & $38(42,20 \%)$ & 0,06 & 0,957 \\
Kurang & $34(37,80 \%)$ & $4(4,40 \%)$ & $3(3,30)$ & $41(45,60 \%)$ & & \\
Total & & & & $90(100 \%)$ & & \\
\hline
\end{tabular}

\section{BAHASAN}

Responden dalam penelitian ini ialah ibu kandung dari anak batita yang menjadi sampel penelitian. Dari hasil penelitian diperoleh responden yang berusia 15-25 tahun sebanyak 64 orang (71\%); usia 26-35 
tahun sebanyak 25 orang (27\%); sedangkan yang berusia di atas 35 tahun 1 orang $(1,1 \%)$. Dapat dilihat bahwa responden yang berusia 15-25 tahun lebih banyak dibandingkan yang lain. Semakin dewasa usia maka tingkat kemampuan dan kematangan dalam berpikir dan menerima informasi lebih baik dibandingkan dengan usia yang masih muda atau belum dewasa. Usia juga menjadi faktor penentu dalam tingkat pengetahuan, pengalaman, keyakinan, dan motivasi sehingga umur mempengaruhi perilaku seseorang terhadap objek tertentu. ${ }^{15}$

Responden yang merupakan tamatan SD yaitu 37 orang $(41,1 \%)$, SMP 34 orang (37\%), SMA 16 orang $(17,8 \%)$, sedangkan yang paling sedikit ialah tamatan perguruan tinggi yaitu 3 orang $(3,3 \%)$. Pendidikan merupakan salah satu hal penting dalam perubahan perilaku maupun tingkat pendidikan seseorang, khususnya yang berhubungan dengan gizi. Pendidikan formal ibu mempengaruhi tingkat pengetahuan ibu dimana semakin tinggi pula tingkat pengetahuan ibu untuk menyerap pengetahuan praktis dalam lingkungan formal maupun non formal terutama melalui media massa, sehingga ibu dalam mengolah, menyajikan dan membagi sesuai yang dibutuhkan. ${ }^{16}$

Pekerjaan responden sebagian besar ialah ibu rumah tangga sebanyak 78 orang $(86 \%)$ dan sebagian kecil lainnya yang bukan merupakan ibu rumah tangga sebanyak 17 orang (14\%) terdiri dari mahasiswi, pedagang, perawat gigi, petani, sedang sekolah, dan tambang. Profesi sebagai seorang ibu rumah tangga lebih memungkinkan seorang ibu untuk memantau pertumbuhan dan perkembangan maupun asupan anak setiap harinya.

Berdasarkan hasil penelitian yang diperoleh, ibu yang memiliki tingkat pengetahuan gizi yang kurang yaitu 41 orang $(45,6 \%)$; persentase ini lebih tinggi jika dibandingkan dengan ibu yang berpengetahuan sedang yaitu 38 orang $(42,2 \%)$ dan baik yaitu 11 orang $(12,2 \%)$.

Ketersediaan gizi untuk makanan pendamping ASI berhubungan dengan penyuluhan gizi dan berdampak positif terhadap pertumbuhan linier. ${ }^{17}$ Penyediaan makanan pendamping ASI mempunyai hubungan signifikan dengan pendidikan ibu. Demikian pula penelitian di India menyatakan kenaikan berat badan pada makanan pendamping ASI lebih berat 500 gram pada kelompok yang terdidik dibandingkan yang tidak terdidik yang hanya bertambah 90 gram. ${ }^{11}$ Demikian pula penelitian yang dilakukan di Bangladesh menyatakan lebih efektif pemberian pada kelompok ibu yang berpendidikan. ${ }^{17}$

Seseorang yang berpendidikan rendah belum tentu kurang mampu menyusun makanan yang memenuhi persyaratan gizi dibandingkan dengan orang lain yang pendidikannya lebih tinggi. Sekalipun berpendidikan rendah, kalau orang tersebut rajin mendengarkan atau melihat informasi mengenai gizi, pengetahuan gizinya akan lebih baik.

Dari hasil penelitian pada Tabel 5, terdapat 75 batita dengan asupan energi kurang, sedangkan yang memiliki asupan energi cukup sebanyak 8 batita dan asupan energi lebih 9 batita. Ditemukan sebagian besar sampel memiliki asupan energi di bawah rata- rata untuk batita (1-3 tahun) yaitu 1125 Kkal per hari menurut AKG 2013.

Dari data food recall 24 jam, sebagian besar responden memiliki kebiasaan makan yang keliru, dengan porsi yang tidak teratur dan tidak tepat. Kadang berlebih, kadang kurang dari asupan energi yang seharusnya dikonsumsi. Sampel dengan kategori kurang disebabkan karena jenis dan jumlah makanan yang dikonsumsi tidak sesuai dengan kebutuhan. Pada usia mereka zatzat gizi yang dibutuhkan cukup tinggi. Energi dapat timbul karena adanya pembakaran karbohidrat, protein dan lemak, karena itu agar energi tercukupi, perlu mengonsumsi makanan yang cukup dan seimbang. ${ }^{11}$

Hubungan antara pengetahuan gizi ibu dengan kecukupan asupan energi batita dianalisis dengan uji Spearman. Dari hasil analisis diketahui tidak ada hubungan yang bermakna. Pada Tabel 6, responden pada 
kelompok yang memiliki tingkat pengetahuan gizi baik dengan kecukupan energi kurang terdapat 9 orang; kecukupan energi cukup terdapat 2 orang; sedangkan kecukupan energi lebih tidak ada. Hal ini membuktikan bahwa meskipun memiliki pengetahuan baik, belum tentu dapat memberikan asupan energi baik.

Pada tingkatan pengetahuan ibu kategori sedang, ditemukan 32 anak batita yang memiliki asupan energi kurang; 2 anak batita dengan asupan energi cukup; dan 4 batita dengan asupan energi lebih. Hal ini mungkin disebabkan ibu memiliki pengetahuan sedang tentang gizi, belum tentu diterapkan seutuhnya, selain itu juga dapat dipengaruhi faktor-faktor lain seperti usia ibu yang terlalu muda, kesiapannya untuk mengurus anak belum terlalu matang, dan juga kurangnya asupan energi yang diperoleh dari makanan karena latar belakang sosial dan ekonomi keluarga yang berbeda-beda.

Pada tingkatan pengetahuan ibu kategori kurang ditemukan 34 batita dengan asupan energi kurang, tetapi ada juga 4 batita dengan asupan energi cukup dan 3 batita dengan asupan energi lebih. Hal ini dapat disebabkan meskipun memiliki tingkat pengetahuan rendah tentang gizi, asupan makanan dapat terpenuhi karena ketersediaan pangan yang mencukupi setiap hari.

Berdasarkan hasil penelitian yang dilakukan tentang pengetahuan gizi ibu dan asupan energi batita menunjukkan dua hal yang tidak berhubungan. Hal ini memperlihatkan bahwa ibu yang memiliki pengetahuan tentang gizi baik pada umumnya bekerja dan tidak dapat fokus dalam memberikan asupan energi yang baik pada anaknya. Ditemukan juga ibu dengan pengetahuan rendah pada umumnya hanya menjadi ibu rumah tangga tetapi beberapa dari mereka dapat mengontrol asupan energi yang baik untuk anaknya. Faktor lain yang dapat memengaruhi hal ini misalnya pengambilan data food recall 24 hours yang dilakukan dengan tidak tepat, adanya the flat slope syndrome dimana saat pengambilan data responden melaporkan asupan yang lebih banyak ataupun sebaliknya, atau dari pola makan responden yang memiliki kebiasaan makan yang buruk, kurang adanya pemahaman pada saat dilakukan recall, dan juga dapat terjadi kesalahan saat pengukuran antropometri dan konversi data dari ukuran rumah tangga ke bentuk energi yang underestimate. ${ }^{17}$

\section{SIMPULAN}

1. Ibu di Desa Mopusi yang memiliki pengetahuan gizi dengan kategori baik sebanyak 11 orang $(12,2 \%)$, sedang 38 orang $(42 \%)$, dan kurang sebanyak 41 orang $(45 \%)$.

2. Asupan energi anak batita dari responden di kategori kurang sebanyak 75 orang (83\%), cukup sebanyak 8 orang $(8,9 \%)$, dan lebih sebanyak 7 orang $(7,8 \%)$

3. Tidak ada hubungan antara tingkat pengetahuan gizi ibu dengan kecukupan asupan energi batita di Desa Mopusi Kecamatan Lolayan Kabupaten Bolaang Mongondow Induk $(r=0,06$ dan $\mathrm{p}=0,957)$.

\section{SARAN}

1. Ibu lebih meningkatkan pengetahuan gizi yaitu dengan rajin mengikuti penyuluhan gizi di posyandu maupun menyerap informasi di media cetak atau elektronik, serta meningkatkan pengawasan terhadap status gizi anak batita dengan rutin membawa ke posyandu

2. Petugas kesehatan diharapkan dapat meningkatkan pengetahuan gizi masyarakat melalui penyuluhanpenyuluhan pada saat kegiatan PKK, posyandu, dan lain-lain.

3. Pemerintah daerah maupun pusat sebaiknya lebih memperhatikan lagi masalah kurangnya asupan energi yang terjadi di wilayahnya.

4. Perlu diadakan penelitian yang lebih lanjut tentang faktor-faktor yang memengaruhi asupan energi batita dengan cakupan yang lebih luas, mengingat bahwa penelitian ini hanya 
membahas mengenai salah satu faktor yang mempengaruhi status gizi batita yaitu pengetahuan gizi ibu.

\section{DAFTAR PUSTAKA}

1. United Nations: MDG. Goal 4: Child mortality [Internet]. [cited 28 April 2013]. Available from: http://www.un.org/millenniumgoals/c hildhealth.shtml

2. WHO. Child mortality [Internet]. 2011 [cited 28 April 2013]. Available from:http://www.who.int/pmnch/ media/press_materials/fs /fs_mdg4_childmortality/

3. Pelletier DL, Frongillo EA, Schroeder DG, Habicht JP. The effects of malnutrition on child mortality in developing countries. Bull WHO. 1995;73(4):443-8.

4. Drake L. Maicer C. Jukes, $M$ and Patrikios. School age children: Their nutrition and health. Patnership of child Development, 2002.

5. Atmarita. Nutrition problem in Indonesia, Artikel disampaikan pada seminar dan workshop Gaya hidup hubungannya dengan penyakit. Universitas Gadjah Mada. 2005.

6. Arisman. Gizi dalam Daur Kehidupan, In: Widyastuti P, editor. Buku Ajar Ilmu Gizi. Jakarta: EGC, 2004.

7. Lassi ZS, Das JR, Zahid G, Imdad A, Bhutta ZA. Impact of education and provision of complementary feeding on growth and morbidity in children less than 2 years of age in developing countries: A systematic review. BMC Public Health. 2013;13(Suppl 3): s.13.

8. Hariyani S. Gizi untuk Kesehatan Ibu dan Anak. Makassar: Graha Ilmu, 2011.
9. Rencana Aksi Nasional Pangan dan Gizi 2011-1015. Available from:http://www.bappenas.go.id/getfile-server/node/10655.

10.Standar Kecukupan Gizi dan Perencanaan Pemenuhannya. Available from: http://zaifbio.wordpress.com/2009/02 /02standart-kecukupan-gizi-danperencanaan-pemenuhannya/.

11.Dewey KG, Afarwuah SA. Systematic review of evicacy and effectiveness of complementary feeding interventions in developing countries. Mother and Child Nutrition, 2008; 4(Suppl. SI):24-85.

12.13Jacqueline C. Dietitian's Guide to Assessment and Documentation. New York: Jones and Bartlett Publishers, LLC; 2011.

13.14Notoatmodjo S. Ilmu Kesehatan Masyarakat, Prinsip-Prinsip Dasar; Jakarta: PT Rineka, 2003.

14.12Almatsier S. Prinsip Dasar Ilmu Gizi. Jakarta: Gramedia Pustaka Utama; 2009; p. 42,44,72,99.

15.Susanti R, Indriati G, Utomo W. Hubungan pengetahuan ibu tentang gizi dengan status gizi anak usia 1-3 tahun. JOM PSIK. 2014;1(2):1-7.

16.Simanjuntak NE. Gambaran pengetahuan ibu tentang pola pemberian ASI, MPASI dan pola penyakit pada bayi 0-12 bulan di Dusun III Desa Limau Manis Kecamatan Tanjung Kabupaten Deli Serdang [Skripsi]. Medan: FKM Universitas Sumatra Utara; 2007.

17. Imdad A, Yakoob MY, Bhutta ZA. Impact of maternal education about complementary feeding and provision of complementary foods on child growth in developing countries. BMC Public Health. 2011;11(Suppl 3): 525. 